Research Article

Mutagenesis

\title{
Cytotoxic and genotoxic evaluation of cotinine using human neuroblastoma cells (SH-SY5Y)
}

Daiana Dalberto ${ }^{1}$, Caroline Cardoso Nicolau ${ }^{1}$, Ana Leticia Hilario Garcia ${ }^{1,2}$, Adriane Perachi Nordin ${ }^{1}$, Ivana Grivicich $^{3}$ and Juliana da Silva ${ }^{1,4}$ iD

${ }^{1}$ Universidade Luterana do Brasil (ULBRA), Programa de Pós-Graduação em Biologia Celular e Molecular Aplicada à Saúde - PPGBioSaúde, Laboratório de Toxicologia Genética, Canoas, RS, Brazil.

${ }^{2}$ Universidade Feevale, Programa de Pós-Graduação em Qualidade Ambiental, Laboratório de

Ecotoxicologia, Novo Hamburgo, RS, Brazil.

${ }^{3}$ Universidade Luterana do Brasil (ULBRA), Programa de Pós-Graduação em Biologia Celular e Molecular Aplicada à Saúde - PPGBioSaúde, , Laboratório de Biologia de Cancer, Canoas, RS, Brazil.

${ }^{4}$ Universidade La Salle, Programa de Pós-Graduação em Saúde e Desenvolvimento Humano, Canoas, RS, Brazil.

\begin{abstract}
Cotinine is the main metabolite of nicotine, which is metabolized in the liver through a cytochrome P450 enzyme. Different studies point to genetic instability caused by nicotine, such as single and double DNA strand breaks and micronuclei formation, but little is known about the effect of cotinine. Therefore, the present in vitro study assessed the effects of cotinine on cell viability and DNA damage in SH-SY5Y neuroblastoma cells, as well as genotoxicity related to oxidative stress mechanisms. Comparisons with nicotine were also performed. An alkaline comet assay modified by repair endonucleases (FPG, OGG1, and Endo III) was used to detect oxidized nucleobases. SH-SY5Y neuronal cells were cultured under standard conditions and exposed for $3 \mathrm{~h}$ to different concentrations of cotinine and nicotine. Cytotoxicity was observed at higher doses of cotinine and nicotine in the MTT assay. In the trypan blue assay, cells showed viability above $80 \%$ for both compounds. Alkaline comet assay results demonstrated a significant increase in damage index and frequency for cells treated with cotinine and nicotine, presenting genotoxicity. The results of the enzyme-modified comet assay suggest a DNA oxidative damage induced by nicotine. Unlike other studies, our results demonstrated genotoxicity induced by both cotinine and nicotine. The similar effects observed for these two pyridine alkaloids may be due to the similarity of their structures.
\end{abstract}

Keywords: Cotinine, nicotine, cytotoxicity, genotoxicity, SH-SY5Y cells.

Received: April 18, 2019; Accepted: July 11, 2019.

\section{Introduction}

Nicotine is an alkaloid found in tobacco leaves (Nicotiana tabacum), a plant native from the Americas (Schroff $e t$ al., 2000; El-Sakka, 2010; Lee et al., 2015; Sinditabaco, 2017). The metabolism of nicotine occurs mainly in the liver through cytochrome P450 enzymes, mainly CYP2A6. Approximately $70 \%$ to $80 \%$ of nicotine is metabolized into cotinine, an alkaloid considered toxic (Hukkanen et al., 2005; Henningfield et al., 2009). There is evidence that cotinine may lead to the same effects as nicotine, probably due to structural similarity (Figure 1) (Grizzell and Echeverria, 2015).

Agricultural workers engaged in tobacco cultivation are constantly exposed to nicotine, which is present in the

Send correspondence to Juliana da Silva. Universidade Luterana do Brasil (ULBRA), PPGBioSaúde, Laboratório de Toxicologia Genética, Prédio 22, Av. Farroupilha 8001, 92425-900, Canoas, RS, Brazil. E-mail: juliana.silva@ulbra.br. plant leaves. According to Da Silva et al. (2010), Fassa et al. (2014), and Mishra et al. (2015), the tobacco producers who have contact with tobacco leaves at the harvest period, often humid, are at risk of intoxication. This acute nicotine intoxication is known as Green Tobacco Sickness (GTS), and is caused by transdermal absorption of the substance. Nicotine also enters the bloodstream almost instantly and crosses the blood-brain barrier within seconds (Luttrell and Vogel, 2014; Raja, 2016), thus affecting human behavior, central and peripheral nervous systems, and cardiovascular and endocrine systems, among other problems (Sassone, 2011).

GTS is only related with nicotine. Although the action of cotinine in humans is still poorly understood, it is known to have a longer biological half-life than nicotine. Nicotine is rapidly removed from the central nervous system (1-3 hours), while cotinine remains in the organism for a longer period (10-30 hours) (Sassone, 2011; Katner et al., 2015). The accumulation of high concentrations of cotinine in the brain, along with its pharmacological potential, suggests that 

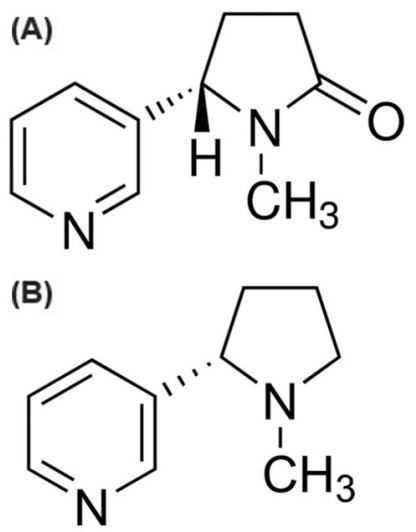

Figure 1 - Chemical structure of cotinine (A) and nicotine (B).

cotinine should be examined for its possible involvement in the nicotine effect and dependence (Katner, 2015).

Different studies have tested potential carcinogenic effects of cotinine, but evidence is inconclusive, due to the lack of studies with adequate desing and conflicting or incomplete results (Haussmann and Fariss, 2016). Although there is also no evidence that nicotine alone causes cancer (Luttrell and Vogel, 2014), different studies using different experimental designs point to genetic instability caused by nicotine (Kleinsasser et al., 2005; Attia, 2007; Sobkowiak and Lesicki, 2009; Da Silva et al., 2010; Lomazzo et al., 2011; Nishioka et al., 2011; Ginzkey et al., 2012, 2013, 2014; Kahl et al., 2012; Gao et al., 2014; Sanner and Grimsrud, 2015).

Human neuroblastoma cell lines are commonly used in studies related to neurotoxicity, oxidative stress, and neurodegenerative diseases (Krishna et al., 2014). These cell lines are used in in vitro experiments that require neuron-like cells (Kovalevich and Langfor, 2013). Therefore, this study aimed to evaluate cytotoxic and genotoxic effects, and to detect oxidative stress caused by different concentrations of nicotine and cotinine through the modified comet assay using the human neuroblastoma cell line SH-SY5Y.

\section{Material and Methods}

\section{Cell culture}

Human neuroblastoma cells (SH-SY5Y) were purchased from Rio de Janeiro Cell Bank (BCRJ, Duque de Caxias, RJ, Brazil). The cell line was established in 1970 from a metastatic bone tumor. Neuroblastoma (NB) derived cell lines carry the wild-type p53 gene with a p53-dependent apoptotic pathway.

Cell cultures were maintained under specific standard conditions in humid atmosphere at $37{ }^{\circ} \mathrm{C}$ and $5 \% \mathrm{CO}_{2}$, in DMEM/F12 medium (Dulbecco's Modified Eagle's Medium/Ham's Nutrient Mixture F12) supplemented with fetal bovine serum (FBS) (10\%) and stabilized (1\%) antibiotic antimycotic solution (100X).

For the MTT [3-(4,5-dimethyl-2-thiazolyl)-2,5-diphenyl-2H-tetrazolium bromide], trypan blue, alkaline comet, and modified comet assays, cells $\left(1 \times 10^{5}\right)$ were seeded in complete medium and cultured in 24-well plates to allow cell adhesion. The determination of the concentrations of nicotine and cotinine followed the International Standard ISO/EN10993-5 (2009). In each well, the concentrations of cotinine $(2.0,1.0,0.5,0.25$, and $0.125 \mathrm{mg} / \mathrm{mL})$ and nicotine $(2.0,1.0,0.5,0.25,0.125 \mu \mathrm{L} / \mathrm{mL})$ were added, as well as DMEM/F12 medium as a negative control and dimethyl sulfoxide (DMSO 20\%) or hydrogen peroxide $\left(\mathrm{H}_{2} \mathrm{O}_{2} 2 \mathrm{mM}\right.$ ) as a positive control. For the modified comet assay, only the concentrations of $2.0,0.5$, and $0.125 \mathrm{mg} / \mathrm{mL}$ for cotinine and 2.0, 0.5 , and $0.125 \mu \mathrm{L} / \mathrm{mL}$ for nicotine were used. Compounds were purchased from Sigma-Aldrich. The culture medium DMEM/F12 was used for the dilution of the compounds.

\section{Cell viability assay}

To determine the cytotoxicity, the colorimetric assay of MTT was performed following the International Standard ISO/EN10993-5 (2009) and Mosmann (1983), with minor modifications.

After the treatments, the cells were washed with DPBS, incubated with $150 \mu \mathrm{L} /$ well of MTT solution (1 $\mathrm{mg} / \mathrm{mL}$ in DPBS) in phenol-free culture medium at $37^{\circ} \mathrm{C}$ for $3 \mathrm{~h}$. After incubation, the supernatant was carefully removed and the violet formazan crystals were solubilized in $100 \mu \mathrm{L}$ DMSO.

The absorbance reading of the formazan crystals, which is directly proportional to the number of viable cells, was performed using an ELISA reader with a wavelength of $540 \mathrm{~nm}$ (Multiskan, UNISCIENCE). The tests were performed in duplicate.

The trypan blue method is widely used to evaluate cytotoxicity in experimental investigations (Avelar-Freitas et al., 2014). The principle of the assay is that living cells have an intact plasma membrane that prevents the internalization of dyes, such as trypan blue. The evaluation occurs through the analysis of cells in a hemocytometer, in which the uncolored cells represent the viable cells and the bluecolored are the non-viable cells (Louis and Siegel, 2011). The experiments were performed in duplicate.

In addition to the aforementioned concentrations, the assay had a negative control (DMEM/F12 medium) and a positive control $\left(2 \mathrm{mM} \mathrm{H}_{2} \mathrm{O}_{2}\right)$. After 3 hours of exposure, the cells were trypsinized for $3 \mathrm{~min}$ in $5 \% \mathrm{CO}_{2}$ at $37^{\circ} \mathrm{C}$ and centrifuged for $3 \mathrm{~min}$ at $1500 \mathrm{rpm}$. The supernatant was removed and cells were resuspended with culture medium. Cells were then homogenized with $0.4 \%$ trypan blue dye in the ratio 1:1 (dye:cell homogenate) and subsequently membrane integrity was assessed by reading in an automated cell counter. The results are reported as the total percentage of viable cells, in both the MTT assay and the trypan blue assay.

\section{Alkaline comet assay}

The cell preparation was done as aforementioned. The negative control used was DMEM/F12 medium and the positive control was $2 \mathrm{mM} \mathrm{H}_{2} \mathrm{O}_{2}$. 
The alkaline comet assay was performed as described by Singh et al. (1988) and modified by Da Silva et al. (2000). After a 3-hour treatment, SH-SY5Y cell suspensions $(20 \mu \mathrm{L})$ were dissolved in $80 \mu \mathrm{L}$ of low melting agarose and arranged in microscope slides pre-coated with a layer of $1 \%$ normal melting point agarose. After solidification of the mixture the slides were dipped in lysis buffer $(2.5 \mathrm{M} \mathrm{NaCl}, 100 \mathrm{mM}$ EDTA, 10 mM Tris, pH 10.0 - 10.5) containing 1\% (v/v) Triton X-100 and 10\% (v/v) of DMSO, protected from light.

After 1 hour in the lysis buffer, the slides were placed in horizontal electrophoresis cuvettes and covered with alkaline buffer solution $(300 \mathrm{mM} \mathrm{NaOH}$ and $1 \mathrm{mM}$ EDTA, $\mathrm{pH}>$ 13) prepared at the time of use, at $4{ }^{\circ} \mathrm{C}$ for $20 \mathrm{~min}$ in order to facilitate DNA unwinding. The DNA was then electrophoresed for $15 \mathrm{~min}$ at $25 \mathrm{~V}(0.90 \mathrm{~V} / \mathrm{cm})$ and $300 \mathrm{~mA}$. Subsequently, the slides were neutralized with $0.4 \mathrm{M}$ Tris buffer solution ( $\mathrm{pH} 7.5)$ and stained with silver nitrate solution.

The analysis was performed on 100 cells per treatment (50 per slide) using a light microscope. Cells were classified into different classes of damage from 0 to 4 , being class 0 : undamaged, without a tail; class 1: with tail shorter than the diameter of the head (nucleus); class 2: with tail 1-2 times longer than the diameter of the head; class 3: with a tail 2 times longer than the diameter of the head; class 4: significant damage, with a long tail, measuring more than 3 times the diameter of the head. A value (damage index, DI) was assigned to each comet according to its class. DI ranged from 0 (completely undamaged: 100 cells X 0) to 400 (with maximum damage: 100 cells X 4). Each concentration was tested in quadruplicate from two independent experiments.

\section{Modified comet assay}

For the modified comet assay with endonucleases, cells were prepared in the same way as for the conventional comet assay until the slides were removed from the lysis solution.

The modified comet assay was performed according to Collins et al. (1993). When the slides were removed from the lysis solution, they were washed three times with buffer solution (400 mM Hepes, $1 \mathrm{M} \mathrm{KCl,} 5 \mathrm{mM}$ EDTA, $2 \mathrm{mg} / \mathrm{mL}$ BSA, pH-8.0) and then incubated at $37{ }^{\circ} \mathrm{C}$ with enzyme buffer supplemented with formamidopyrimidine DNA glycosilase (FPG) (1 $\mu \mathrm{g} / \mathrm{mL}$ solution), endonuclease III (Endo III) $(1 \mu \mathrm{g} / \mathrm{mL}$ solution) for $45 \mathrm{~min}$, and DNA glycosylase (OGG1) $(1 \mu \mathrm{g} / \mathrm{mL}$ solution) for $30 \mathrm{~min}$ in a humid chamber. After this step, the slides were placed in a horizontal electrophoresis chamber and covered with alkaline buffer solution (300 $\mathrm{mM} \mathrm{NaOH}$ and $1 \mathrm{mM}$ EDTA, $\mathrm{pH}>13$ ) freshly prepared, remaining for $40 \mathrm{~min}$. The DNA was then electrophoresed for $15 \mathrm{~min}$ at $25 \mathrm{~V}(0.90 \mathrm{~V} / \mathrm{cm})$ and $300 \mathrm{~mA}$. Neutralization, staining, and damage assessment occurred as described for the conventional alkaline comet. Arbitrary units from the alkaline comet assay (without enzyme) represent the DNA strand breaks. Sensitive sites were calculated by subtracting the arbitrary units of the test without enzyme from the arbitrary units of the enzyme-treated test. The experiments were performed in quadruplicate.

\section{Statistical analysis}

For the statistical analysis between the different concentrations of the samples, the univariate analysis of variance (ANOVA) was used followed by the Kruskal-Wallis or Tukey's test using GraphPad Prism 5.0 software, with a value of $p<0.05$ considered as indicative of statistical significance.

\section{Results}

Results for the MTT assay demonstrated cytotoxicity in neuroblastoma cells above $70 \%$ for concentrations greater than $0.25 \mathrm{mg} / \mathrm{mL}$ of cotinine and greater than $0.5 \mu \mathrm{L} / \mathrm{mL}$ of nicotine (Figure 2A). For the cell viability assay with trypan blue, cells presented cell viability above $80 \%$ for all concentrations, for both cotinine and nicotine, not exhibiting high cytotoxicity (Figure 2B). The results showed no significant difference for MTT and trypan blue results between groups ( $p>0.05$; ANOVA, Tukey's test).

The alkaline comet assay presented significant results for the damage index and frequency, for both cotinine and nicotine compounds. These results demonstrated induction of genotoxicity in human neuroblastoma cells $(p<0.05$; ANOVA, Kruskal-Wallis test) (Table 1).

The modified comet assay (FPG, OGG1, and Endo III) demonstrated no significant increase in total DNA damage in SH-SY5Y cells exposed to cotinine and nicotine (Figure 3 ) at all concentrations, except at 0.5 and $2 \mu \mathrm{L} / \mathrm{mL}$ of nicotine using FPG ( $p<0.05$; Kruskal-Wallis test).

\section{Discussion}

Studies on the genotoxicity of nicotine are still controversial, and little is known about its major metabolite, cotinine (Wise and Bozarth, 1987). Our study evaluated the cytotoxic and genotoxic effects of cotinine and nicotine in a human neuroblastoma cell line using the alkaline comet assay.

Cytotoxicity was evaluated using two methods, the MTT assay, which evaluates mitochondrial activity through mitochondrial respiration and can be used to assess cellular energy capacity (Mosman, 1983, Meerloo and Cloos, 2011), and the trypan blue assay, which evaluates the integrity of the cell membrane (Avelar-Freitas et al., 2014). Cell viability evaluation is a useful tool for different experimental procedures (Avelar-Freitas et al., 2014). We observed very similar results between cotinine and nicotine in both assays. The MTT results indicated that concentrations of 0.25 and $0.125 \mathrm{mg} / \mathrm{mL}$ of cotinine and $0.5,0.25$, and $0.125 \mu \mathrm{L} / \mathrm{mL}$ of nicotine showed viability above $70 \%$, when compared to the negative control $(100 \%)$, in 3 hours of exposure, indicating that cytotoxicity can reduce cell viability in a dose-dependent manner.

Higher cytotoxicity was found at the highest concentrations of both cotinine $(2.0,1.0$, and $0.5 \mathrm{mg} / \mathrm{mL})$ and nicotine $(2.0$ and $1.0 \mu \mathrm{L} / \mathrm{mL})$. In the trypan blue assay, low cytotoxicity was observed for the SH-SY5Y cell line, since all concentrations for both compounds showed cell viability 


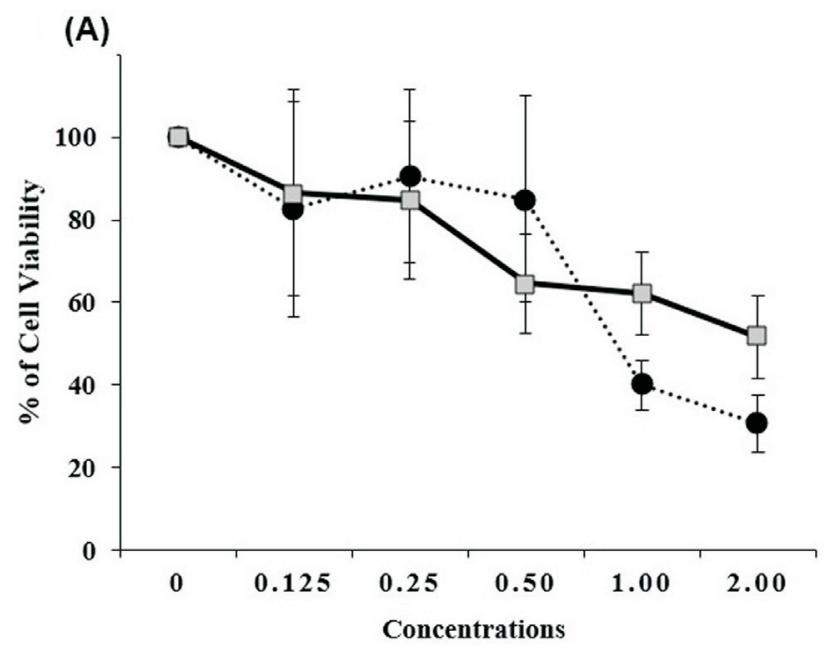

(B)

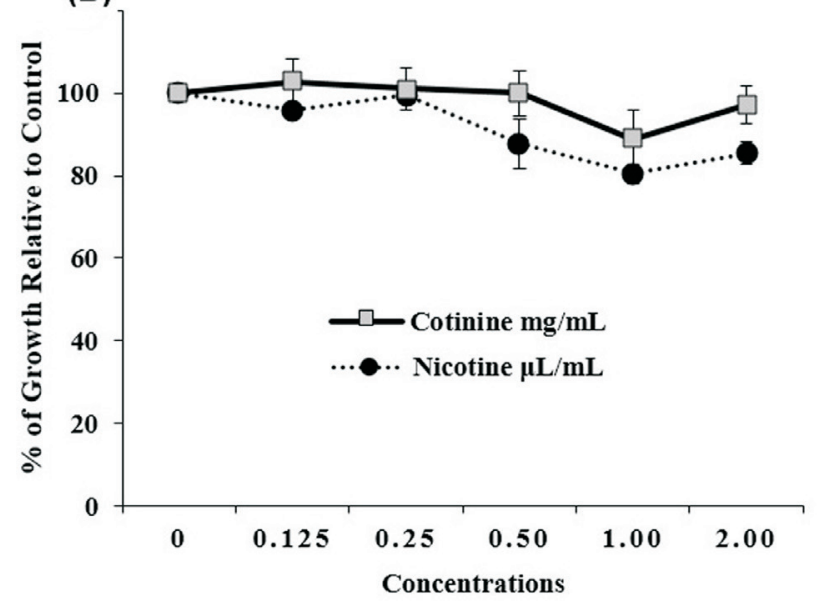

Figure 2 - Cell viability evaluation of SH-SY5Y using the MTT assay (A) and using the Trypan Blue assay (B) after cotinine and nicotine treatment $(3 \mathrm{~h})($ mean $\pm \mathrm{SE})$. Experiments conducted in quadruplicate.

$>80 \%$. Similar to our study, other studies have also demonstrated nicotine cytotoxicity in the MTT assay in different cell lines, including human cells (Kang et al., 2011; Zeng et al., 2012). Wang et al. (2014) have shown that cell viability was significantly inhibited by nicotine in a dose- and timedependent manner. The study by Ginzkey et al. (2009) evaluated cytotoxicity via the trypan blue test, where cells exposed to nicotine were not harmed, presenting cell viability higher than $80 \%$. Using other tests to evaluate cytotoxicity, such as human fibroblast cells and hepatocellular carcinoma, other authors have also demonstrated similar nicotine and cotinine responses (Babich and Borenfreund, 1992; Esfahrood et al., 2015). In order to evaluate the genotoxicity of cotinine and nicotine in human neuroblastoma cells, an alkaline comet assay was performed. The results of this assay showed genotoxicity in cells exposed to cotinine and nicotine, for damage index and frequency. Higher concentrations of nicotine $(1-2 \mu \mathrm{L} / \mathrm{mL})$ induced an increase in DI greater than 3-fold, and cotinine $(1-2 \mathrm{mg} / \mathrm{mL})$ resulted in an increase greater than two-fold when compared to the negative control. It was not possible to observe a dose-response in the comet assay, possibly because cytotoxicity occurred at higher concentrations as in the MTT test.

The results of the MTT assay indicate that the cell metabolism stopped after exposure to cotinine or nicotine, but no membrane damage was detected, as evidenced by the trypan blue assay. Together with the genotoxicity data, it is likely that DNA damage is so extensive that it killed the cells, explaining the cytotoxic effects. These effects may be explained by oxidative damage due to decreased mitochondrial function induced by cotinine/nicotine, leading to an increase in DNA damage followed by cell death. It is well established that when producing ATP through oxidative phosphorylation, mitochondria also are the major site of intracellular reactive oxygen species (ROS) production. Mitochondria themselves are susceptible to ROS, and injured mitochondria produce higher levels of ROS that cause further mitochondrial dysfunction (Lin and Beal, 2006). The excess of ROS also causes oxidative damage to DNA, proteins, and lipids. In DNA, ROS can provoke single- and double-stranded DNA breaks (Evans et al., 2004),

Data from previous studies already point to DNA damage caused by exposure to nicotine (Ginzkey et al., 2012, $2013,2014)$, as demonstrated in our study through the exposure of SH-SY5Y to different concentrations of nicotine. Although different studies in the literature point to the genotoxicity of nicotine, and only few were done for cotinine, it can be inferred that the DNA damage observed in vivo in rodents is induced by both alkaloids, since nicotine is mostly metabolized into cotinine (and cotinine remains for a long time in the body). Likewise, Kahl et al. (2012) and Da Silva et al. (2013) through the comet assay and micronucleus test have demonstrated that nicotine was genotoxic and mutagenic in mice. While the comet assay revealed DNA damage that can be repaired, micronuclei are biomarkers of loss or breaks of entire chromosomes that cannot be repaired. Evidence suggests that exposure to nicotine may interfere with different cellular processes that are considered important for the promotion or progression of carcinogenic processes. Studies have reported that nicotine stimulates cell proliferation, induces cell migration, inhibits apoptosis, induces angiogenesis, and inhibits immune functions. Haussmann and Fariss (2016) reviewed studies related to nicotine and cancer, showing that the majority of studies $(\sim 70 \%)$ provide sufficient evidence to conclude that nicotine can stimulate carcinogenesis in animals. The role of nAChRs has been emphasized in the process of triggering intracellular signaling pathways, which in turn influence the carcinogenic process (Haussmann and Fariss, 2016).

As mentioned before, the comet assay is a widely used method for assessing DNA damage and, with modifications, it is possible to evaluate different types of DNA damage. Through improvements, the assay became more sensitive and confirmatory in relation to mechanisms of oxidative damage (Collins, 2014). In order to understand the mechanisms of action of cotinine and nicotine, we used the comet assay modified by repair endonucleases with FPG, OGG1, 
Table 1 - Evaluation of DNA damage in SH-SY5Y cells treated with cotinine and nicotine. Results are reported as mean \pm standard deviation.

\begin{tabular}{lcc}
\hline Groups & Damage Index (0-400) & Damage Frequency (\%) \\
\hline Negative Control & $75.82 \pm 64.17$ & $41.41 \pm 24.77$ \\
Cotinine & & \\
$0.125 \mathrm{mg} / \mathrm{mL}$ & $151.25 \pm 30.39^{\mathrm{b}}$ & $67.50 \pm 11.85^{\mathrm{c}}$ \\
$0.250 \mathrm{mg} / \mathrm{mL}$ & $176.50 \pm 32.14^{\mathrm{c}}$ & $72.25 \pm 9.91^{\mathrm{c}}$ \\
$0.500 \mathrm{mg} / \mathrm{mL}$ & $171.50 \pm 46.26^{\mathrm{c}}$ & $78.00 \pm 13.29^{\mathrm{c}}$ \\
$1.00 \mathrm{mg} / \mathrm{mL}$ & $151.50 \pm 19.36^{\mathrm{b}}$ & $74.75 \pm 7.04^{\mathrm{c}}$ \\
$2.00 \mathrm{mg} / \mathrm{mL}$ & $201.25 \pm 66.77^{\mathrm{c}}$ & $85.00 \pm 11.46^{\mathrm{c}}$ \\
Nicotine & & \\
$0.125 \mu \mathrm{L} / \mathrm{mL}$ & $171.00 \pm 38.93^{\mathrm{a}}$ & $75.00 \pm 17.76^{\mathrm{c}}$ \\
$0.250 \mu \mathrm{L} / \mathrm{mL}$ & $139.75 \pm 15.92^{\mathrm{a}}$ & $69.00 \pm 9.90^{\mathrm{c}}$ \\
$0.500 \mu \mathrm{L} / \mathrm{mL}$ & $208.25 \pm 59.35^{\mathrm{b}}$ & $87.50 \pm 11.45^{\mathrm{c}}$ \\
$1.00 \mu \mathrm{L} / \mathrm{mL}$ & $250.75 \pm 71.62^{\mathrm{c}}$ & $88.25 \pm 10.90^{\mathrm{c}}$ \\
$2.00 \mu \mathrm{L} / \mathrm{mL}$ & $308.00 \pm 88.54^{\mathrm{c}}$ & $92.50 \pm 8.35^{\mathrm{c}}$ \\
Positive Control & $253.60 \pm 104.38^{\mathrm{c}}$ & $85.80 \pm 20.63^{\mathrm{c}}$ \\
\hline
\end{tabular}

${ }^{\mathrm{a}}$ Statistical significance compared to negative control at $p<0.05,{ }^{\mathrm{b}}$ at $p<0.01$, and ${ }^{\mathrm{c}}$ at $p<0.001$ ) (Kruskal-Wallis test). ${ }^{\mathrm{d}} \mathrm{H}_{2} \mathrm{O}_{2}-2 \mathrm{mM}$.

and Endo III enzymes. The use of the enzymes led to increased DNA damage by both cotinine and nicotine compared to the positive control, but only the highest concentrations of nicotine presented significantly higher results when using the FPG enzyme when compared to the negative control. Through the FPG enzyme, it is possible to detect the presence of altered purines (Langie et al., 2015). Some of the damaged bases that are recognized and removed by FPG include 8-oxoG, 8-oxoadenine, fapy-guanine, methy-fapyguanine, fapy-adenine, aflatoxin B1-fapy-guanine, 5-hydroxy-cytosine, and 5-hydroxy-uracil (Hatahet et al., 1994; Tchou et al., 1994). The enzyme OGG1 recognizes only 8-oxoG, and the enzyme Endo III detects oxidized pyrimidines (Kuznetsov et al., 2015). According to our results it is possible to suggest that nicotine was capable of inducing oxidized purines.

According to Aguiar et al. (2013), the action of cotinine and nicotine is related to oxidative stress, which can result in DNA lesions, leading to genomic instability and cell death. Guanine is considered the most susceptible base to oxidation due to the low redox potential, with 8-oxoG being considered the most common damage. Regarding oxidative damage, Da Silva et al. (2010) have demonstrated an increase in catalase (CAT), which is responsible for decomposing hydrogen peroxide into water and oxygen, in mice exposed to nicotine. Additionally, Kahl et al. (2012) demonstrated the potential of vitamin $\mathrm{C}$ in reducing the genotoxicity of nicotine. These studies demonstrated that nicotine affects the action of the superoxide dismutase, catalase, and glutathione reductase (Yildiz, 2004), indicating an oxidative stress mechanism in the DNA damage caused by nicotine.

The oxidation process is endogenous and causes considerable DNA damage. The imbalance between the formation and removal of ROS can contribute to degenerative

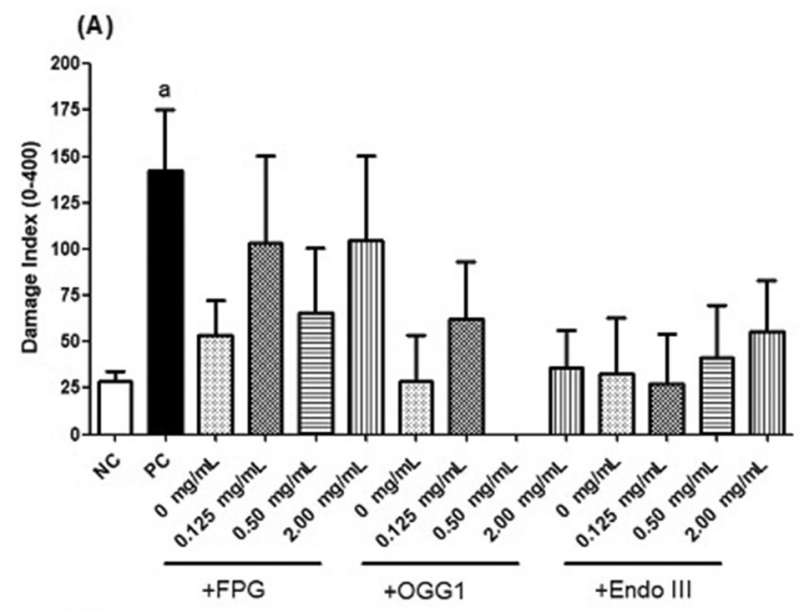

(B)

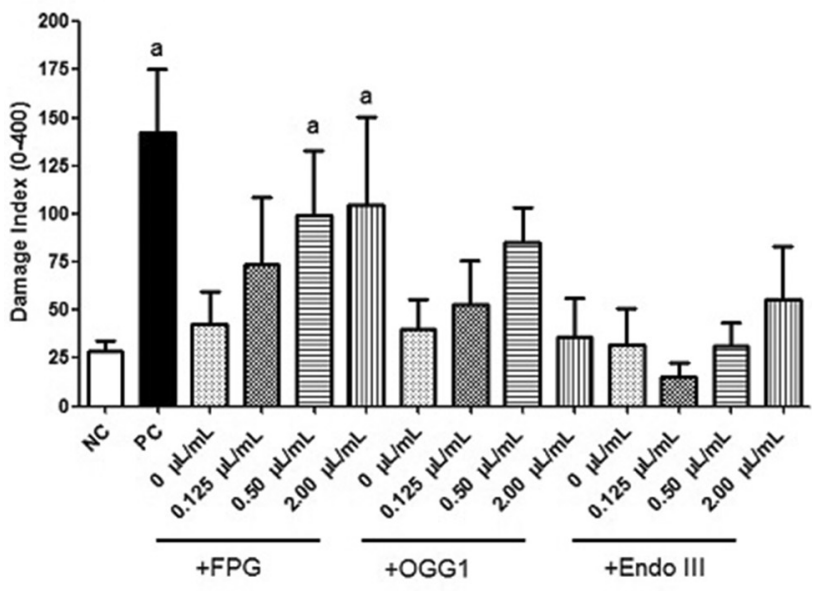

Figure 3 - Damage index results (mean $\pm \mathrm{SD}$ ) obtained with modified comet assay using FPG, OGG1 and Endo III sensitive sites on SH-SY5Y

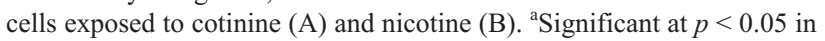
relation to negative control $(\mathrm{NC}$; without enzyme $=$ strand breaks) (Kruskal-Wallis test). PC: Positive control $\left(\mathrm{H}_{2} \mathrm{O}_{2}: 2 \mathrm{mM}\right.$; without enzyme). Oxidative DNA damage (cells exposed to enzymes) was calculated as the difference between the scores obtained before and after incubation with the respective enzyme or the buffer.

diseases such as cataracts, Parkinson's disease, diabetes, cancer, and aging in general. These highly reactive species can form a wide variety of mutagenic DNA adducts. DNA attacks by ROS can cause the formation of 8-oxo-7,8-dihydro-2'-deoxyguanosine (8-oxodG), which is formed by the hydroxylation of deoxyguanosine in DNA. Chronic exposure to nicotine may increase the production of ROS via the Ras pathway in rats with potential DNA damage and cell cycle deregulation, as well as an increase in nitric oxide (NO) that may play a role in nicotine genotoxicity (Ginzkey et al., 2012). In addition, Feltes et al. (2013) using biology systems demonstrated that nicotine may be related to oxidative imbalance of the cell and affect cellular proliferation.

In conclusion, our study indicated that cotinine and nicotine induced cytotoxicity and DNA damage to exposed cells. The similar DNA damage effects observed for these two pyridine alkaloids may be due to the similarity of their structures. The results of the modified comet assay using en- 
zymes demonstrated oxidized purine bases suggesting an oxidizing nature in DNA damage in cells treated with nicotine. In addition, our results demonstrated that cotinine could be also related to the DNA damage observed in individuals exposed to nicotine, and as far as we know, this is the first study on the effect of cotinine on DNA.

\section{Acknowledgments}

The authors thank the Conselho Nacional de Desenvolvimento Científico e Tecnológico (CNPq), Coordenação de Aperfeiçoamento de Pessoal de Nível Superior (CAPES Finance Code 001) and Fundação de Amparo à Pesquisa do Estado do Rio Grande do Sul (FAPERGS) for financial support.

\section{Conflict of Interest}

The authors declare not conflict of interest.

\section{Author Contributions}

DD and JS designed the study and wrote the article; DD, CCN, APN, ALHG and IG performed the experiment; DD, ALHG, IG and JS analyzed the data; all authors read and approved the final version.

\section{References}

Aguiar PH, Furtado NC, Repole BM, Ribeiro GA, Mendes IC, Peloso EF, Gadelha FR, Macedo AM, Franco GR, Pena SDJ et al. (2013) Oxidative stress and DNA lesions: The role of 8-oxoguanine lesions in Trypanossoma cruzi cell viability. PLoS Negl Trop Dis 7:e2279.

Attia SM (2007) The genotoxic and cytotoxic effects of nicotine in the mouse bone marrow. Mutat Res 15:29-36.

Avelar-Freitas BA, Almeida VG, Pinto MCX, Mourão FAG, Massensini AR, Martins-Filho OA, Rocha-Vieira E and BritoMelo GEA (2014) Trypan blue exclusion assay by flow cytometry. Braz J Med Biol Res 47:307-315.

Babich H and Borenfreund E (1992) Cytotoxic and morphological effects of phenylpropanolamine, caffeine, nicotine, and some of their metabolites studied In vitro. Toxicol In Vitro 6:493502.

Collins A (2014) Measuring oxidative damage to DNA and its repair with the comet assay. Biochim Biophys Acta 1840:794800.

Collins A, Duthie S and Dobson V (1993) Direct enzymic detection of endogenous oxidative base damage in human lymphocyte DNA. Carcinogenesis 14:1733-1735.

Da Silva J, De Freitas ORT, Heuser V, Marinho RJ, Bittencourt F, Cerski STC, Kliemann ML and Erdtmann B (2000) Effects of chronic exposure to coal in wild rodents (Ctenomys torquatus) evaluated by multiple methods and tissues. Mutat Res Genet Toxicol Environ Mutagen 470:39-51.

Da Silva FR, Erdtmann B, Dalpiaz T, Nunes E, Da Rosa PD, Porawski M, Bona S, Simon FC, Allgayer DCM and Da Silva J (2010) Effects of dermal exposure to Nicotiana tabacum (Jean Nicot,1560) leaves in mouse evaluated by multiple methods and tissues. J Agric Food Chem 58:9868-9874.

Da Silva FR, Erdtmann B, Dalpiaz T, Nunes E, Ferraz A, Martins TLC, Dias JF, Da Rosa DP, Porawskie M, Bona S et al.
(2013) Genotoxicity of Nicotiana tabacum leaves on Helix aspersa. Genet Mol Biol 36:269-275.

El-Sakka MA (2010) Phytochemistry (3) Alkaloids. 3rd edition. Al Azhar University, Cairo.

Esfahrood ZR, Zamanian A, Torshabi M and Abrishami M (2015) The effect of nicotine and cotinine on human gingival fibroblasts attachment to root surfaces. J Basic Clin Physiol Pharmacol 26:417-522.

Evans MD, Dizdaroglu M and Cooke MS (2004) Oxidative DNA damage and disease: Introduction, repair and significance. Mutat Res 567:1-61.

Fassa AG, Faria NMX, Meucci RD, Fiori NS, Miranda VI and Facchini LA (2014) Green Tobacco Sickness among tobacco farmers in Southern Brazil. Am J Ind Med 57:726-735.

Feltes BC, Poloni JF, Notari DL and Bonatto D (2013) Toxicological effects of the different substances in tobacco smoke on human embryonic development by a systems chemo-biology approach. PLoS One 8:e61743.

Gao H, Prasad GL and Zacharias W (2014) Combusted but not smokeless tobacco products cause DNA damage in oral cavity cells. Environ Toxicol Pharmacol 37:1079-1089.

Ginzkey C, Kampfinger K, Friehs G, Köhler C, Hagen R, Richter E and Kleinsasser NH (2009) Nicotine induces DNA damage in human salivary glands. Toxicol Lett 184:1-4.

Ginzkey C, Stueber T, Friehs G, Koehler C, Hackenberg S, Richter E, Hagen R and Kleinsasser NH (2012) Analysis of nicotine-induced DNA damage in cells of human respiratory tract. Toxicol Lett 208:23-29.

Ginzkey C, Friehs G, Koehler C, Hackenberg S, Hagen R and Kleinsasser HN (2013) Assessment of nicotine-induced DNA damage in a genotoxicological test battery. Mutat Res 751:34-39.

Ginzkey C, Steussloff G, Koehler C, Burghartz M, Scherzed A, Hackenberg S, Hagen R and Kleinsasser HN (2014) Nicotine derived genotoxic effects in human primary parotid gland cells as assessed in vitro by comet assay, cytokinesis-block micronucleus test and chromosome aberrations test. Toxicol In Vitro 28:838-846.

Grizzell JA and Echeverria V (2015) New insights into the mechanisms of action of cotinine and its distinctive effects from nicotine. Neurochem Res 40:2032-2046.

Hatahet Z, Kow YW, Purmal AA, Cunningham RP and Wallace SS (1994) New substrates for old enzymes. J Biol Chem 269:18814-18820.

Haussmann HJ and Fariss MW (2016) Comprehensive review of epidemiological and animal studies on the potential carcinogenic effects of nicotine per se. Crit Rev Toxicol 46:701-734.

Henningfield JE, London ED and Pogun S (2009) Nicotine Psychopharmacology (Handbook of Experimental Pharmacolology 192). Springer, Berlin, pp v-viii.

Hukkanen J, Jacob P3rd and Benowitz NL (2005) Metabolism and disposition kinetics of nicotine. Pharmacol Rev 57:79-115.

Kahl SFV, Reyes MJ, Sarmento SM and Da Silva J (2012) Mitigation by vitamin $\mathrm{C}$ of the genotoxic effects of nicotine in mice, assessed by the comet assay and micronucleus induction. Mutat Res 744:140-144.

Kang SW, Park HJ, Ban JY, Chung JH, Chun GS and Cho JO (2011) Effects of nicotine on apoptosis in human gingival fibroblasts. Arch Oral Biol 56:1091-1097.

Katner NS, Toalston EJ, Smoker PM, Rodd AZ, McBride JW and Engleman AE (2015) Time-course of extracellular nicotine and cotinine levels in rat brain following administration of nicotine: effects of route and ethanol coadministration. Psychopharmacology (Berl) 232:551-60. 
Kleinsasser NH, Sassen AW, Semmler MP, Harréus UA, Licht AK and Richter E (2005) The tobacco alkaloid nicotine demonstrates genotoxicity in human tonsillar tissue and lymphocytes. Toxicol Sci 86:309-317.

Krishna A, Biryukov M, Trefois C, Antony PM, Hussong R, Lin J, Heinäniemi M, Glusman G, Köglsberger S, Boyd O et al. (2014) Systems genomics evaluation of the SH-SY5Y neuroblastoma cell line as a model for Parkinson's disease. BMC Genomics 15:1154.

Kovalevich J and Langford D (2013) Considerations for the use of SH-SY5Y neuroblastoma cells in neurobiology. Methods Mol Biol 1078:9-21.

Kuznetsov NA, Kladova OA, Kuznetsova AA, Ishchenko AA, Saparbaev MK, Zharkov DO and Fedorova OS (2015) Conformational dynamics of DNA repair by Escherichia coli endonuclease III. J Biol Chem 290:14338-14349.

Langie SAS, Azqueta A and Collins AR (2015) The comet assay: Past, present, and future. Front Genet 6:1-3.

Lee Y, Chen R, Chang N, Lee K, Huang C and Huang YHOF (2015) Synergistic impact of nicotine and shear stress induces cytoskeleton collapse and apoptosis in endothelial cells. Ann Biomed Eng 43:2220-2230.

Lin MT and Beal MF (2006) Mitochondrial dysfunction and oxidative stress in neurodegenerative diseases. Nature 443:787795 .

Lomazzo E, Hussmann GP, Wolfe BB, Yasuda RP, Perry DC and Kellar KJ (2011) Effects of chronic nicotine on heteromeric neuronal nicotinic receptors expressed in rat primary cultured neurons. J Neurochem 119:153-164.

Louis KS and Siegel AC (2011) Cell viability analysis using trypan blue: Manual and automated methods. Methods Mol Biol 740:7-12.

Luttrell WE and Vogel HF (2014) Nicotine. Chem Health Saf 21:39-41.

Mishra A, Chaturvedi P, Datta S, Sinukumar S, Joshi P and Garg A (2015) Harmful effects of nicotine. Indian J Med Paediatr Oncol 36:24-31.

Meerloo JV and Cloos J (2011) Cell sensitivity assays: The MTT assay. Methods Mol Biol 731:731-245.

Mosmann T (1983) Rapid colorimetric assay for cellular growth and surviral: Aplication to proliferation and cytotoxicity assays. J Immun Methods 65:55-63.

Nishioka T, Yamamoto D, Zhu T, Guo J, Kim SH and Chen CY (2011) Nicotine overrides DNA damage-induced $\mathrm{G}_{1} / \mathrm{S}$ restriction in lung cells. PLoS One 6:e18619.

Raja M, Garg A, Yadav P, Jha K and Handa S (2016) Diagnostic methods for detection of cotinine level in tobacco users: A review. J Clin Diagn Res 10:4-6.
Sanner T and Grimsrud TK (2015) Nicotine: carcinogenicity and effects on response to cancer treatment: A review. Front Oncol 5:1-10.

Sassone AH (2011) Estudio de las alteraciones bioquímicas, histopatolígicas y ultraestructurales producidas por la administración oral a largo plazo de cotinina en ratas: Comparación con nicotina. Acta Toxicol Argent 19:44-45.

Schroff KC, Lovich P, Schmitz O, Aschhoff S, Richter E and Remien J (2000) Effects of cotinine at cholinergic nicotinic receptors of the sympathetic superior cervical ganglion of the mouse. Toxicology 144:99-105.

Singh NP, McCoy MT, Tice RR and Schneider EL (1988) A simple technique for quantification of low levels of DNA damage in individual cells. Exp Cell Res 175:184-191.

Sobkowiak R and Lesicki A (2009) Genotoxicity of nicotine in cell culture of Caenorhabditis elegans evaluated by the comet assay. Drug Chem Toxicol 32:252-257.

Tchou J, Bodepudi V, Shibutani S, Antoshechkin I, Miller J, Grollman AP and Johnson Fl (1994) Substrate specificity of FPG protein: Recognition and cleavage of oxidatively damaged DNA. J. Biol Chem 269:15318-15324.

Wang L, Li X, Zhou Y, Shi H, Xu C, He H, Wang S, Xiong X, Zhang Y, Du Z et al. (2014) Downregulation of miR-133 via MAPK/ERK signaling pathway involved in nicotine-induced cardiomyocyte apoptosis. Naunyn-Schmiedeberg's Arch Pharmacol 387:197-206.

Wise AR and Bozarth AM (1987). A psychomotor stimulant theory of addiction. Psychol Rev 94:469-492.

Yildiz D (2004) Nicotine, its metabolism and an overview of its biological effects. Toxicon 43:619-632.

Zeng F, Li YC, Chen G, Zhang YK, Wang YK, Zhou SQ, Ma LN, Zhou JH, Huang YY, Zhu WY et al. (2012) Nicotine inhibits cisplatin-induced apoptosis in NCI-H446 cells. Med Oncol 29:364-373.

\section{Internet Resources}

ISO/EN10993-5 (2009) International Standard ISO 10993-5 - Biological evaluation of medical devices - Part 5: Tests for cytotoxicity: in vitro methods, https://www.iso.org/standard/36406.html.

Sinditabaco (2017) Sindicato da Indústria do Tabaco, http://sinditabaco.com.br/sobre-o-setor/origem-do-tabaco/ (accessed 06 June 2019).

\section{Associate Editor: Catarina S. Takahashi}

License information: This is an open-access article distributed under the terms of the Creative Commons Attribution License (type CC-BY), which permits unrestricted use, distribution and reproduction in any medium, provided the original article is properly cited. 